\title{
РОЛЬ МЕТАФОРИ У ФОРМУВАННІ УКРАЇНСЬКОЇ КРИМІНАЛІСТИЧНОЇ ТЕРМННОЛОГЇ̈
}

Гапонова Л. Є. Роль метафори у формуванні української криміналістичної термінології.

У статті досліджується метафора як чинник творення криміналістичних термінів, 3'ясовується роль метафори у формуванні української криміналістичної термінології.

Ключові слова: метафора, українська криміналістична термінологія, вторинна номінація, загальновживана лексика.

Гапонова Л. Е. Роль метафоры в формировании украинской криминалистической терминологии.

В статье исследуется метафора как фактор создания криминалистических терминов, выясняется роль метафоры в формировании украинской криминалистической терминологии.

Ключевые слова: метафора, украинская криминалистическая терминология, вторичная номинация, общеупотребительная лексика.

С Л. Є. Гапонова, 2013. 
Gaponova L.E The role of metaphors in the formation of Ukrainian criminalistic terminology.

The article investigates the metaphor as a factor in the creation of criminalistic term, it appears the role of metaphors in the formation of Ukrainian criminalistic terminology.

Key words: metaphor, Ukrainian criminalistic terminology, secondary nomination, common lexicon.

Спосіб найменування, за якого використовуються слова загального вжитку для позначення спеціальних вузькогалузевих понять, у термінології набуває особливого значення, оскільки наукові поняття формувалися на основі узагальнень, отриманих людиною у процесі практичного пізнання світу.

Галузева термінологія виникає переважно на основі живої народної мови, використовуючи іï словотвірні можливості. Зокрема, особливості формування українських галузевих терміносистем зумовлюються структурно-граматичною специфікою національної мови. Водночас термінотворення породжує свої специфічні мовні моделі, що проникаючи в загальнолітературну лексику, розширюють ї словотвірний потенціал. Як показують дослідження словотвору термінологічних одиниць загальнонаукового і галузевого типів, у початковий період формування термінології перевага надається тим способам термінотворення, що спираються на вже наявні мовні ресурси. Найпродуктивнішим на ранніх етапах розвитку галузевих терміносистем є лексико-семантичний спосіб творення термінологічних одиниць.

Одним із продуктивних способів термінотворення $\epsilon$ семантичний, що полягає у зміні значення наявних у мові слів, обсяг застосування якого значно ширший ніж у загальновживаній лексиці. Семантична спеціалізація і пристосування загальновживаних слів до вузькоспеціальної сфери науки займає значно менший період часу. Цей спосіб знаходить своє вираження і в синтаксичних відношеннях, що характеризуються наявністю зв’язаних сполучень, у складі яких один або й обидва компоненти можуть і не бути термінами: прочісування місцевості, очна ставка [10, с. 282], словесний nортрет [3, с. 150], кут зустрічі, фронтальний кут та подібні до них: Проте найбільи докладному опису підягають анатомічні ознаки, які власне утворюють словесний портрет [3, с. 151]; Сутність очної ставки полягає в тому, що слідчй по черзі пропонує кожному з допитуваних дати показання про обставини, у яких виявлено істотні суперечності [8, с. 68].

Мета дослідження - визначення ролі метафори у формуванні терміносистеми криміналістики.

Одним із способів вторинної номінації в термінології найчастіше $\epsilon$ метафора - універсальний інструмент мислення, який передбачає вживання слова, що позначає певний предмет, явище, дію, ознаку для номінації іншого предмета на основі подібності, яка виникає з їхнього порівняння, зіставлення за асоціацією. Проникнення метафори не тільки в терміносистему, а й в інші 
галузі функціонування мови трактується в сучасних теоріях не як відхилення від норми, а як закономірне та природне явище загалом.

Оскільки метафора як складне мовне явище має суперечливу природу, ii дослідження характеризуються не тільки багатоаспектністю, а й багаторівневістю аналізу, причому подібні дослідження здійснюються в різних напрямах, серед яких: лінгвістичний (Арутюнова Н. Д., Бессарабова Н. Д., Русанівський В. М. та ін.), логічний (Тараненко О. О., Уфімцева А. А. та ін.), гносеологічний (Виготський Л. С., Комлєв М. Г. та ін.) і напрям, що грунтується на методі компонентного аналізу, тобто розкладанні одиниць на певні ознаки - семасіологічний (Арутюнова Н. Д., Гак В. Г., Говердовський В. І., Стернін I. А. та ін.). Семасіологічний напрям вивчає семантичні процеси, що формують метафоричні значення, співвідношення сем у вихідному та похідному значеннях, специфіку конотативних елементів; цей напрям вважається провідним у сучасному мовознавстві.

Порівнюючи різноманітні визначення метафори, простежуємо закономірність у тому, що більшість цих визначень основою існування метафори називає взаємодію двох понять, що дає змогу говорити про двоплановість цього явища: 1) метафора, як результат відношення між двома значеннями слова, з яких одне виступає як вихідне, а інше як похідне, є яскравим прикладом динаміки у сфері лексичної семантики (Гак В. Г.); 2) метафора - це семантичний процес, за якого форма мовної одиниці чи оформлення мовної категорії переноситься з одного референта на інший на основі тієї чи тієї подібності останніх при відбитті у свідомості мовця (Тараненко О. О.); 3) метафора - це різновид вторинної лексичної номінації, що передбачає появу на основі значення зіставлення двох предметів за однією ознакою, виникнення якого гарантується єдністю всіх сторін практико-перетворювальної діяльності людини, єдністю процесів, що здійснюються у їі свідомості (Вовк В. М.).

Відмінність нетермінологічних значень від термінологічних - це абстрагувальна властивість людського мислення, що встановлює зв'язки між поняттями науковим із неспеціальної, побутової сфери.

У системі термінолексем криміналістики найчастіше розщеплення семантичної структури термінів відбувається в результаті виникнення нових понять. Нові найменування утворюються внаслідок асоціації за подібністю або суміжністю: поза «боксер» (специфічне положення тіла й кінцівок обгорілого трупа), лист конюшини (револьверний барабан із чотирма каморами; таку назву дістав через свою форму), магазин (вмістилище для патронів); види магазинів: коробка, диск, трубка, ріжковий магазин; личинка (запор затвора у деяких видах вогнепальної зброї), морнінгстар (кістень, посилений шипами - вид зброї), сокіл (бездимний порох колоїдного типу, використовується як мисливський порох) та ін. Або, наприклад, назви моделей зброї глорія [9, с. 58] (італ. 
gloria - сяйво, ореол), вікторія (лат. victoria - перемога) - іспанські автоматичні пістолети калібру 6,35 мм і 7,65 мм; імітація браунінга 1906 р. [9, с. 51], в основі цих лексем лежать ономізовані одиниці.

Відповідно до співвідношення ознак спеціального та загальновживаного значень виділяються такі різновиди лексико-семантичного способу: звуження (спеціалізація) значення загальновживаного слова, використання термінів однієї галузі знань для позначення понять іншої (ретермінологізація), перенесення значення за подібністю (метафоризація), перенесення значення за суміжністю (метонімізація).

Звуження значення загальновживаного слова в термінології тлумачиться по-різному. Однак учені виявляють єдність поглядів щодо необхідної умови процесу термінологізації - щоб слово літературної мови стало терміном, потрібно, щоб відбулася спеціалізація номінативного значення.

Нові термінологічні значення - це лексико-семантичний варіант значення того слова, на основі якого вони формуються. У термінолексиці криміналістики функціонує багато мовних одиниць, лексико-семантична структура яких має початкове загальновживане значення й похідне термінологічне. У функції термінів зазначені слова набувають семантичної мотивованості, оскільки значення їх сформувалося внаслідок переосмислення на основі подібності форми або функції. Підставою похідних значень у термінології є метафора.

3 часом, коли термін стає широковживаним, його метафорична чи метонімічна яскравість утрачається [5, с. 163]. Образність термінів виникає внаслідок метафоричності значень і так само не сприймається в ролі об'єктивного критерію через досить тривале використання загальновживаного слова в контексті української криміналістичної термінології. Наприклад: лама (іспанський автоматичний пістолет калібру 9 мм і 7, 65 мм), боксер (бразильський шестизарядний револьвер 38 спеціального калібру), лось (радянський п'ятизарядний магазинний мисливський карабін калібру 9 мм). Закріплення професійної лексеми чи словосполучення в активі фахівців конкретної галузі знань уже $є$ повноправним критерієм термінної стійкості словосполучень на зразок «свіэсий» слід, «юсирний» слід, «сліпий» слід, сліди взуттяя з малюнком «у ялинку», розщук по «гарячих» слідах [3] у мікротерміносистемі «сліди локомоційних навичок людини». Подібні терміни, оминувши етап перенесення зі сфери функціонування на сферу фіксації й закріплення, принаймні в спеціальній науковій та методичній літературі з криміналістики, засвідчили свій термінологічний статус, мотивованість i водночас продуктивність термінотворення способом вторинної номінації.

На прикладі досліджуваної української криміналістичної термінології простежується продукування термінозначення тими загальновживаними словами, що вже реалізували свою номінативну функцію, але для наукового обгрунтування вузькогалузевої термінолексики зазнають актуалізації власних 
синтагматичних властивостей. Зокрема в терміносистемі криміналістики були створені такі терміни-словосполучення, як польова криміналістика [3, с. 329], погашення судимості [10, с. 306], польові методи [3, с. 84], психологічна засідка [3, с. 28], холодна зброя [3, с. 306], злом «без шуму» (віджим) [3, с. 261].

У термінології поширене таке явище, як використання в ролі термінів слів загальнолітературної мови в метафоричному значенні, тобто відбувається зворотний процес, коли слова загальновживаної лексики змінюють своє значення на основі метафоричних і метонімічних переносів і стають термінами, виражаючи свій термінологічний статус у співвіднесеності поняттєвого компонента значення 3 науковим поняттям: лялька, захисна сітка, холодна зброя, гладкий ствол, комп'ютерний вірус, комп'ютерний абордаж, доріжка слідів ніг, туалет трупа, консервація трупа; у дактилоскопії-гачок, місток, вічко, острівецьь тощо. Значення цих слів у загальнолітературній мові та в українській криміналістичній термінології - різні. Проте термін, на відміну від слова, не виконує прагматичної функції у своїй терміносистемі. Він не виражає певних емоцій, почуттів, хоч і не завжди є однозначним. Термін може виходити за межі своєї терміносистеми і бути надбанням суміжних галузей знань, а також вживатися в загальнолітературній мові.

Незаперечним є те, що в криміналістичній лексиці спостерігається загальна тенденція до широкої взаємодії з загальновживаною лексикою, бо навіть за межами спеціальних текстів криміналістичні терміни вживаються не у вузькогалузевих, а в мовленні в переносному значенні: бандитизм, «без суду $i$ слідства», «брудні гроші» (у подальшому виник асоціативний ряд «відмивати» «брудні» гроші), кримінал, розбій [4, с. 377], насильство, облава, обиук, убивча сила [3, с. 303]. Наприклад: Судово-балістичне дослідження зброї для визначення його стану дозволяє встановити: чи $\epsilon$ даний предмет вогнепальною зброєю, чи придатний він для стрільби $і$ які його балістичні характеристики (убивча сила, дальність польоту кулі та ін.) [3, с. 303]; Попенко розказує про своїх знайомих бурсаків; про їх завзяття, про п'яницькі бенкети, про розбої ичілої валки обходу, про попівен, попів, матушок... [4, с. 377]; I нібито не злодій, нічого кримінального за ним не водиться, а злодійкуватий [7, с. 4]; ... в Італї були ліквідовані мафіозні банківські структури, щзо легалізували «брудні гроші» [2, с. 47]. У цьому ж тексті зазначена лексема далі подається як тлумачення попереднього слова: 3 урахуванням сучасних можливостей банків, іниих фінансових інституичій та обсягів коштів, щуо отримує ТОЗ у вигляді прибутків від нелегальної діяльності, можна стверджувати, щуо сьогодні майже неможливо відокремити «крипто-долари» («брудні гроші») від іниого капіталу, не зачіпаючи при цуьому інтересів великих банків [2, с. 47].

При дослідженні української криміналістичної термінології, виявлено терміни, що використовувалися при реєстрації злочинців у центральному (ㄱ Л. Є. Гапонова, 2013. 
бюро та розшукових відділеннях 31 січня 1915 року. А також зафіксовано один 3 типів словотвірної деривації - ономатизація - «різновид деривації, який реалізується втратою загальною назвою здатності до узагальнення і набуття нею здатності називати один предмет з ряду однорідних» [1, с. 87]: пушкарі (зброярі) і пушкарі (злочинці) [3, с. 58], глухонімі (інваліди) і глухонімі (злочинці), коти (тварини) і коти (злочинці) [3, с. 58], гастролери (артисти, що приїхали на гастролі) і гастролери (злочинці) [3, с. 58]. У словнику іншомовних слів лексема гастролери має значення: 1) артист; 2) перен. недобросовісний працівник, який береться за випадкову роботу, не затримується на одному місці» [6, с. 243]. Сучасна криміналістика не користується лексемами на зразок гастролер, кот та ін. як термінами, що використовуються під час реєстрації злочинців. Деякі з тотожних понять зрідка функціонують у професійному мовленні криміналістів як професіоналізми, оскільки своєрідність походження і метафоричність цих понять у наш час змінила їх сферу функціонування - жаргон злочинців і позбавлених волі осіб, який має назву «феня». Наприклад: поняття кот є абревіатурою початкових літер російських слів (коренной обитатель тюрьмы). Сучасне поняття гастролер у криміналістиці виникло внаслідок метонімічного перенесення за подібністю дії й функціонує тільки у професійному мовленні слідчих, фіксація цього поняття в документах підпорядковується розумінню «почерк злочинця». Метафора у криміналістичній термінології відіграє виняткову роль у розв'язанні нестандартних ситуацій, оскільки й сама вона виникає внаслідок зіставлення певних семантичних об'єктів, часто не порівнюваних, метафора апелює до наявного в реципієнта досвіду задля того, аби через асоціації досягти комунікативного ефекту.

Отже, метафоризація як джерело збагачення літературної мови має важливе значення і в утворенні одиниць, що мають специфічну сферу вживання, зокрема в терміносистемах, однією 3 яких $\epsilon$ термінологія криміналістики. Дослідження формування терміносистеми криміналістики дає підстави стверджувати, що на початковій стадії становлення криміналістичної термінології вторинна номінація є одним із продуктивних способів термінотворення.

Дослідження таких термінологічних лексем має велике практичне значення з огляду на те, що «важливо постійно переглядати терміносистеми з погляду їх адекватності суті номінативних понять, з'ясовувати активні моделі термінотворення» [5, с. 5], тому подальше дослідження термінології сприятиме розкриттю логіки побудови термінополів у межах терміносистеми криміналістики, а також системи української сучасної термінології загалом.

\section{Література}

1. Горпинич В. О. Сучасна українська літературна мова. Морфеміка. Словотвір. Морфонологія : [навчальний посібник] / В. О. Горпинич. - К. : Вища шк., 1999. - 207 с.

2. Дорошенко А. Організована злочинність : міжнародний аспект / А. Дорошенко, І. Овсій // Політика і час. - 1997. - № 3 (березень). - С. 41-51. 
3. Криміналістика : [підручник] / П. Д. Біленчук, О. П. Дубовий, М. В. Салтевський, П. Ю. Тимошенко ; за ред. акад. П. Д. Біленчука. - К. : Атіка, 1998. - 416 с.

4. Мирний Панас. Вибрані твори / Панас Мирний. - К. : Дніпро, 1974. - 560 с.

5. Панько Т. І. Українське термінознавство : [підручник] / Т. І. Панько, І. М. Кочан, Г. П. Мацюк. - Львів : Світ, 1994. - 216 с.

6. Словник іншомовних слів : 23000 сл. та термінол. словосполучень / кол. авт. : Л. О. Пустовіт, О. І. Скопненко, Г. М. Сюта, Т. В. Цимбалюк. - К. : Довіра; УНВЦ «Рідна мова», 2000. - 1018 с.

7. Франко І. Я. Твори : в 2 т. Т. 2 : Оповідання / І. Я. Франко. - К. : Дніпро, 1981. - 495 с.

8. Шепітько В. Ю. Довідник слідчого / В. Ю. Шепітько. - К. : Видавничий Дім «Ін Юpe», 2003. - 208 c.

9. Шепітько В. Ю. Криміналістика : енцикл. словник (українсько-російський і російсько-український) : 1500 термінів / В. Ю. Шепітько ; за ред. акад. НАН України В. Я. Тація. - Х. : Право, 2001. - 560 с.

10. Юридичний словник / за ред. В. Г. Гончаренка. - К. : Форум, 2005. - 473 с. 